\title{
Queering heteronormativity at home: older gay Londoners and the negotiation of domestic materiality
}

\author{
Brent Pilkey* \\ The Bartlett School of Architecture, University College London, London, UK
}

(Received 23 March 2012; final version received 14 June 2013)

\begin{abstract}
This article looks at older gay male homemaking experiences of engaging with domestic material objects. Using London as a case study it draws from 11 in-depth semi-structured interviews. These narratives are used to argue that the homemaking practices of older gay men can advance a queer theorised goal of queering heteronormativity. Throughout the article, domestic materiality and participants' relationship to their sexual minority identity forms the central focus; the empirical analysis highlights the obvious, subtle and even hidden ways interviewees subvert heteronormativity through relating to possessions in the home. On top of this, the article also looks to transcript excerpts to show that some interviewees consciously avoid relating their sexuality in the process of engaging with material objects in the home; this too, it is argued, can be understood as a political act challenging normative understandings of home. The article aims to complement a small but growing body of literature situated at the intersection of feminist work on domestic materiality, geographies of gerontology, ageing masculinity and queer theory.
\end{abstract}

Keywords: domestic materiality; queering heteronormativity; homemaking; older gay men; London, UK

\section{Introduction}

Meanings of home for many people are intimately related to the accumulation of material possessions. For instance, Eric, a participant in the study that informs this paper, notes: 'to me a home ultimately absolutely starts to reflect your life. We've travelled, we've acquired things, we've inherited things from our family ... things that all mean something'. Researchers in diverse disciplines including geography, sociology and anthropology have investigated the ways in which material possessions at home are of prime importance in the construction of subjectivity (Tolia-Kelly 2004a, 2004b; Miller 2008). While there have been studies looking at sexuality, materiality and home, few have investigated this triumvirate from an older gay male perspective (Gorman-Murray 2006, 72). And few have explicitly focused on the ways in which investigations of domestic materiality can support a goal of queer theory: the queering of heteronormativity - a concept that I define below. This paper seeks to make a contribution to existing bodies of literature by showing the varied and nuanced ways that materiality can be understood to work towards subverting oppression in public that sexual minorities face. Drawing from interviews conducted with older gay men in London, UK, the paper celebrates the complexity within this study. ${ }^{1}$ Along with showcasing the ways in which some people in this cohort queer heteronormativity in understandable ways, the paper also looks at a handful of research participants who avoid identifying their sexuality through domestic materiality; rather, other aspects of subjectivity

*Email: b.pilkey@ucl.ac.uk 
are constructed through material possessions. Thus, the article highlights the heterogeneous ways that older gay Londoners' homemaking practices work to simultaneously challenge and even, for a few, support (at least on the surface) heteronormative ideals. These experiences show that queering heteronormativity at home is not always an easy-torecognise subversive act; rather a deeper investigation is needed. In an effort to avoid presenting simple representations of queering home through materiality, the article acknowledges the specificity of the findings resulting from methodological implications, which include intersections of class, wealth and comfort in one's sexual minority identity. Thus, the paper offers a specific, rather than generalised, look at older gay male narratives of materiality at home.

The body of the paper consists of four main sections. First I offer a conceptual framework by providing definitions of key terms and concepts that inform the research. The second section focuses on methodological implications. The final two sections make up the empirical analysis of the paper. In the third part I show the diverse ways that older Londoners' things are used to queer home, in obvious, subtle and hidden ways. In the fourth section I look at materiality from another light: I look beyond it to the research participants that do not locate sexuality in the sphere of representation, and in so doing I show how other intersections of identity become more important as they age. By showing how a few interviewees even aim to support idealised representations of domesticity at first glance, this section in particular aims to complicate the argument I put forward that older gay Londoners are queering heteronormativity at home.

\section{Framing the research: key concepts and relevant literature}

As suggested, home for many people is about being among one's own things: the material possessions accumulated in life. Young (2005a, 156) argues, 'home is an arrangement of things in this space, according to the life habits of those who dwell in it'. Or as participant Gerard simply puts it: home is 'where my things are'. And for some mature-age people materiality can take on specific meanings: as one ages and one's 'lifeworld converges on the space of the home, the significance of domestic objects - indeed, their signifying capacity - is amplified' (Gorman-Murray 2013, 110). In this section, I begin to outline the conceptual framework of this paper by looking at domestic materiality. I start here deliberately, as it constitutes the main lens of focus in this research and the one that connects the various themes of the paper together. In taking this focus, this article aims to extend feminist geographical work on domestic materiality by making the case that material culture in the home is of particular importance to some older gay men. I then go on to work through relevant literature and key concepts - including heteronormativity, geographical gerontology and masculinities - which relate to the empirical analysis of domestic materiality in order to make the case that material possessions are an important angle to investigate older gay men's homes. In making this contribution, I build on a point made by Tolia-Kelly. Looking at the primary role material culture has in constituting belonging and citizenship for South Asian women whose identity and homes have been shaped by post-colonial migration across multiple geographies, Tolia-Kelly (2004b, 677, 678) makes the case that objects in the home are particularly important for this marginalised group: 'The presence of visual and material cultures in the homes of South Asians post-migration operate as counter weights to the experience of disenfranchisement in the British landscape and the experience of marginalisation.' Put another way, 'South Asian identity is figured through being and living in the British landscapes of exclusionary and marginalising national culture.' Although there are clear differences in the papers and 
conceptual framework, both look to marginalised groups in London, whose history of exclusion have shaped their relationship to domestic materiality.

Gorman-Murray offers a similar suggestion when he notes that material objects are particularly important for sexual minorities 'whose sense of self includes subjectivities which are marginalized, and thus not affirmed or easily performed in the public sphere' $(2008,284)$. Many older gay men - particularly the ones in this study - came to terms with their sexual identity in an era when it was illegal to publicly declare oneself as gay and material possessions can play a key role throughout the lifecourse in the construction of subjectivity for some people. Kennedy observes that queer oral history is sensitive to such contextualising information: "not being born and raised in a public lesbian and gay culture, each gay and lesbian person has to construct his or her own life in oppressive contexts, a process that oral history is uniquely suited to reveal' $(2006,272)$.

Investigating the interconnected relationship between material objects and home has been a thread of homemaking literature (Morrison 2013, 415). For instance, Miller (2008, 152) has suggested that domestic possessions underwrite subjectivity through their realisation of identity in concrete rather than abstract form: '.. they just serve, in their relatively humble way, as forms through which relationships are expressed and developed'. Noble (2004) extends this by arguing that the accumulation and arrangement of objects at home are materialisations of our ongoing construction of subjectivity: these objects are physical realisations of personal meanings and interpersonal social relations.

Another stream in the research focuses on the mutually constitutive relationship between personal and societal, domestic and public, consumption practices (Miller 1987). Cook (forthcoming) contributes to this point when he suggests that analyses of home as a material space and a container of ideas recalls the social organisation of people and society. Relatedly, material homemaking offers the chance for multiple 'fractured or fragmented identities' to come together in one space; these might include 'sexual identities with familial, ethnic-cultural and spiritual, inter alia' (Gorman-Murray 2008, 284, 283). Young offers a similar argument that sees the 'affirmation of personal and cultural identity' requiring 'material expression in meaningful objects arranged at home' (2005b, 146). This research points to the fact that domestic materiality is 'meaningful beyond [a] textual representation' (Tolia-Kelly 2004b, 685). In other words, as I go on to show, domestic materiality is not simply an unconscious collection of objects in the home; it necessitates an in-depth investigation of personal embodied narratives, of the ways in which 'these texts are livedwith', where older gay men's homes are shaped by public and life-long experiences of negotiating identity in a heteronormative society (Tolia-Kelly 2004b, 686). Thus, there is a clear link between domestic materiality and heteronormativity as well as other related power constructs that shape experiences of home.

Heteronormativity can be defined '[as] the processes that socially construct a privileged heterosexuality (and related binary understandings of gender) over homosexuality and unconventional presentations of gender' (Brown 2009, 1496; see also Hubbard 2008). Human sexuality - the preference for sexual object choice, which goes far beyond sexual acts - is intimately tied to this concept. At the level of culture and society the dominant sexuality works to oppress all other expressions. Challenging heteronormative social and legitimate sexual and gender relations is one of the tenets of queer theory. As suggested, the trappings of heteronormativity are deep-rooted in our society. Hegemonic masculinity for instance - the system which links 'manliness' to the male sex - is deeply ingrained in our culture and continues to shape experiences of home for the participants in this study. This brief discussion begins to construct a conceptual foundation to support the following literature review paragraphs and subsequent analysis. Simply put, these regimes - which 
indeed they are - converge in the homemaking process of relating to materiality - the collection, display and engagement of physical objects across the lifecourse which reinforce one's subjectivity and history (Buchli 2004).

In order to focus on the lens of domestic materiality in older gay Londoners' homes it is necessary to contextualise the work on geographical gerontology, which has been implicitly heterosexual in focus with few exceptions (including: Gorman-Murray 2013; Jones and Pugh 2005; Waitt and Gorman-Murray 2007; Slevin and Linneman 2010). This body of work has seen several valuable foci; moreover, it generally has a social justice goal in mind, namely to understand and hopefully work to improve inequalities and oppression relating to everyday life experiences of ageing (Milligan 2009). Thus, this general aim fits with the aspirational goal of the paper, which works towards overturning oppressive heteronormativity. One of the main approaches within the gerontological literature has been the turn to emotional embodiment, wherein 'The body is not taken for granted as a fixed entity ... [but rather] can take different forms and shapes at different times' (McDowell 1999, 39). In other words, recognising that home for older people is a key physical and emotional space of identity, embodiment points to the importance of personal and ever-changing subjectivity across the lifecourse, which, as I go on to show below, relates back to and layers the negotiation of materiality for this cohort. Related to this, has been a turn to ageing-in-place, where solutions are sought to encourage older people to remain in their homes as they age (Milligan 2009; Andrews et al 2007). All of this reinforces the importance of home as a crucial space of identity and well-being for this group (Gorman-Murray 2013, 98; Chaudhury and Rowles 2005; Milligan 2009).

While it has been shown that ageism is something older people face at home, one approach has been to look to the specificity of gay ageism. As Wahler and Gabbay (1997) observe, there are several unique challenges that older lesbian and gay men face, including an accelerated sense of ageing, particularly among men: 'where some gay men exhibit heightened concern with body identity and 'feel old' at a younger age than heterosexual men' (Gorman-Murray 2013, 98; see also Pugh 2002, 177; Jones and Pugh 2005; Drummond 2006; Slevin and Linneman 2010). As a result of an obsession with youth in our culture, older gay men can find themselves excluded. Research participant Roger is one of them: he notes, 'I found as I've got older ... I haven't been to Soho in ages [one of London's gay commercial clusters]; I went once in 3.5 years ... I just don't think I identify very much, particularly as I've got older, with the whole gay [scene]'. It can be argued that older gay men in particular negotiate their identity in terms of dual layers of ageism: gay ageism, with its obsession with youthful culture, and mainstream homophobic ageism. In light of this double marginalisation, older gay men as well as other sexual minorities find themselves excluded from public zones (Gorman-Murray 2013, 102; Jones and Pugh 2005, 258).

There is a clear link between homophobia, heteronormativity and ageism that older gay men face, but in the past extensive homophobic policy and social discourse shaped this group's experience of sexuality. Pugh suggests that as a result of the sociopolitical inequality this group has been 'extremely successful [at maintaining] anonymity' (2002, 162). The implications of oppressive history is an ongoing factor in the identity process, particularly as older sexual minorities continue to age and begin to rely on homecare providers (Pugh 2002, 163; see also Coleman 1993; Percival 2002). Macdona (2009) offers a poignant point: 'The fear of having to discuss the subject of sexuality and reveal personal circumstances to healthcare workers and organisations is one significant problem for a large proportion of elderly gay people.' Therefore, paying attention to the experiences of home for older gay generations is important for researchers and governmental bodies alike. 
Another fruitful stream of research within the gerontological literature that relates to this study is that which looks to masculinities. One particular valuable contribution has been the investigation of masculinity and domesticity as co-constitutive and interrelational. Varley and Blasco $(2001,117)$ have shown in their research on masculinities in urban Mexico that 'the difficulties facing some elderly men are intimately connected to the way in which older men are devalued or "degendered" by hegemonic masculinities'. Similarly, in their study looking at working-class and middle-class experiences of 'old age' in Northern English towns, Pain, Mowl, and Talbot found that 'those who are seen to have characteristics of working-class people, femininity or disability are more likely to be embodied with negative characteristics of ageing' (2000,379). These authors, like Varley and Blasco, argue 'that older working-class men in particular lose 'value' on retirement from paid work and thus experience a difficult transition' to a life at home (Pain, Mowl, and Talbot 2000, 381, 380). And in their article investigating the ageing body and homespace, Mowl, Pain, and Talbot (2000) argue that attachment to home is influenced by identity factors such as among others, health status and gender. Particularly for men who are used to working outside of the home, they find that the importance of home is renegotiated in one's retirement years (Mowl, Pain, and Talbot 2000, 193). Although the research data from Mowl, Pain, and Talbot. are drawn from mostly heterosexual respondents, the experiences of ageing and home for gay men can be unique, and indeed more research is needed in this field. I attempt to respond to this lacuna in what follows.

Along with looking to key definitions and relevant literature, this conceptual framework has drawn together insight from feminist work on domestic materiality, geographical gerontology (including work on masculinities) and queer theory to underscore the need for research focusing on older gay male experiences of home. Moreover, what becomes clear is that in light of widespread heteronormativity, significant meaning is invested in the domestic environment and the material possessions that fill it - which for some, as I go on to show, intimately relates to sexual minority subjectivity. Before getting to the empirical discussion, which argues that negotiations of domestic materiality can work to queer heteronormativity at home in multiple ways, I first move to highlight the methodological implications.

\section{Methodology}

The data for this paper are drawn for the most part from 11 semi-structured in-depth interviews that were conducted as part of a larger ongoing research project on home and sexual minority identity among non-heterosexual Londoners (Pilkey 2013). Research for the larger project consisted of in-depth investigations of 40 lesbian, gay, bisexual, transgender and queer (LGBTQ) households, specifically interviews with 33 singles and 7 couples, a total of 47 homeowners or renters ranging in age from early 20 s to late 70 s. Elsewhere, I have discussed generational issues relating to younger lesbian and gay Londoners (Pilkey 2012); however, this paper focuses on older interviewees in their 50s, $60 \mathrm{~s}$ and $70 \mathrm{~s}$. Each interview lasted between $50 \mathrm{~min}$ and two and a half hours, with an average of one hour, and took place over the first six months of 2011. Our conversations, with a few exceptions, were held in either the participant's home or at a gay café in central London. Respondents were recruited through social networking advertisements and posters and through word of mouth. All respondents self-identified as gay, lesbian, bisexual or transgender and self-selected to be part of the research.

As a result of recruitment methods, most of the interviews with older participants were with gay men. This lead to many gay men putting me in touch with friends who shared a 
similar age and gender. In total, in 11 interviews, I was able to interview 13 older gay men (two were with couples). The transcripts offer some notable similarities: all respondents were educated, were from a white background, were from working-class to middle-class backgrounds, and had access to wealth and the desire to make a home. While this data sample does not represent a large enough pool to offer generalisations, it does offer a snapshot of a sample of older gay male Londoners' engagement with material possessions.

The article also draws from a secondary methodology beyond interviewing: a one-weeklong optional participant diary. Due to a number of reasons, including busy schedules and the time commitment needed, only two older interviewees completed the diary, which included seven different writing themes that expanded on home-related topics discussed in the interviews. In-depth analyses based on the interview data and writing diaries consisted of coding by hand and with computer software as well as completing several intensive readings of interview transcripts.

Both the primary and secondary methodologies as well as the analysis phase made me conscious of my own positionality as a young researcher investigating older gay Londoners' homes. In particular generational differences between researcher and researched were raised, with frequent comments like 'back in my day' or 'you younger people have it easier'. It is important to acknowledge how one's position as a researcher might affect the outcome of the interviewing process; positionality influences 'not only the accounts given' but also the 'interpretation of those' (Mowl, Pain, and Talbot 2000, 190; England 1994). If I were of a similar age to this cohort these fruitful discussions around memories of negotiating one's sexual identity in an oppressive era may not have been shared with the same desire to inform and educate (but of course other issues could have been raised including shared similar life experiences and memories).

In analysing interviews with older gay Londoners, two themes emerged: some respondents related their material possessions to their minority subjectivity, while others actively avoid this link in the process of homemaking. However, as I aim to show throughout this article, such a simple dichotomy without further clarification can be misleading and risks reproducing structural binaries: indeed older gay Londoners' experiences of materiality are anything but straightforward. I now turn to explore the multiple ways materiality unfolds in more detail.

\section{Materiality at home}

Taking a social constructivist approach where objects, bodies and houses emerge 'as the outcome of an ongoing production process', where dominant discourses invest them with meaning, I begin the empirical analysis by recognising that, unflinchingly, the domestic sphere has been constructed as the primary site of patriarchal and heterosexual relations in which all others who do not fit into this mould must resist (Baydar 2012, 699; see also Hubbard 2008, 643). In light of this, one of the most easily recognisable ways in which negotiations of materiality work to queer heteronormativity at home is through the affirmation of sexuality with homoerotic artwork. Darrell, for instance, notes: 'I've got a little African stone carving with a huge cock ... a couple of paintings of nice looking men'. Devin's home was also used to display objects of an erotic nature. After stating that 'it's not hard to pick out that a gay man lives here, particularly from the artwork', he then pointed out an explicit nude male calendar in his kitchen. Devin's home is particularly interesting because of the museum-like qualities invested in the interior decoration. He notes: ' . . in the hallway there are club flyers and stuff that I bought over the years. And in the sitting room there are photographs of the England Rugby team when they did their 
naked shots which I bought'. The consciousness to which these have been placed in his home is evident in that six months prior to our interview he had 'a mass clear out', therefore he notes 'what's in the house now are things that I know I want ad infinitum'.

Devin's home, with its homoerotic artwork, flyers from his younger clubbing days and the odd explicit photograph, is a clear example of how objects can take on subversive meanings and challenge the social construction of heteronormativity. Devin's artwork can be understood in another light, too. On his walls multiple aspects of his identity are simultaneously displayed - his love for horses and his attraction to the male body - thus supporting the point that 'various objects embody different facets of self' (GormanMurray 2008, 286).

A handful of other older interviewees also used artwork in the construction of sexual minority subjectivity, yet in less explicit ways. Gerard commented that a few pieces of artwork relate to his sexual identity: 'I've got a little statue that I keep next to my bed called Adam and Steve. I'll go get it and show it to you. It's a South African artist who specialises in this style'. The figurine artistically depicted two male nudes in a non-explicit pose and its location in the bedroom out of view from visitors who come into the home is telling. Simply put, only invited visitors would see the object. The position of homoerotic objects - whether explicit or otherwise - within view of the home's occupier, yet out of reach from visitors, is one way to be selective and control who sees sexual identifying material possessions, yet there are other ways objects might be mediated. Gerard continues:

I've got a few other [objects of interest, such as this one,] it's pottery. It's glazed and if you turn it over it's got male genitalia engraved underneath. It's one of those things that you go 'that's very nice' then you turn it over and go 'AHHH'.

The display of this object in Gerard's home queers heteronormativity in a unique way. Through the mediated display of objects, the home may seem on first glance to be just like any heteronormative home. Gerard shared an interesting story of a visit to a friend's house that highlights the way one could use dual-functioning artwork to, when one wishes, make the home appear heteronormative, but then at other times queer the space.

In the case of homoerotic artwork, whether explicit or otherwise, the body becomes sexualised only when read in terms of the owner's own gay subjectivity. Of course not all artwork in older gay Londoners' homes relates to the male body, and indeed many respondents mentioned other art that was important in the construction of subjectivity. It is these lessobvious material possessions, I argue, that begin to show interesting ways heteronormativity can be queered. Continuing to look at Gerard's home highlights how personal narratives can uncover the hidden ways artwork plays a role in the construction of identity:

I suppose the things I value the most are the artworks ... The artwork is not overtly sexual ...

[I have a piece called] The Diva of Luca, which is by a fairly well known artist that lives in Italy. I had a house in Italy, so I suppose you could say I was identifying myself with it (because that was my nick-name).

Thus, by playing on the term 'diva', which is a trope linked to many gay cultural figures and is a gay stereotype generally, Gerard observes that this painting speaks to his own gay subjectivity. Gerard observes an interesting point: 'you might say that a single heterosexual man probably wouldn't have [this or] Hayden ballet prints on the wall, he would probably have David Beckham scoring a goal'. This reference to homemaking offers an example of the diverse ways in which masculinity plays out at home.

Similar to Gerard's subjective explanation of the above artwork, through the link of diva identity, Dean felt his expansive CD collection, one of his most valued possessions, relates 'without any doubt' to his sexual minority subjectivity: 
I suppose I identify being into opera to a certain degree with being gay, because there is a great gay following of opera with gay icons. Thinking about Maria Callas, and there is a lot of divaishness with it all. So yes I suppose [it does relate]. Ninety five per cent of my CDs are opera and musicals, you see so I must be gay!

Dean's small north London flat is filled with his CD collection. In addition, in the entryway he has a framed photograph of diva opera singer Maria Callas. Thus, through the process of interviewing Dean and understanding the meaningfulness of his CD collection - and in light of the cultural associations where 'among affluent males the diva effect tends to produce a devotion to sopranos [like] Maria Callas' (Brett and Wood 2006, 369; see also Koestenbaum 1993, especially Chapter 4 'The Callas Cult') - it became clear that opera music is one way in which his domestic environment subtly queers home.

Like Devin discussed above, who noted the objects in his home will remain ' $a d$ infinitum', Dean spoke of his home decorating, now 'in its fourth reincarnation', as essentially complete. The meaningfulness of his CD collection is clear in that living in a small flat has necessitated, over the years, conscious decisions on what to keep and what to throw away. He observes, 'yes, absolutely' all objects have meaning, 'I would have gotten rid of it if they didn't ... Everything here means something to me'. In her ethnographic study of 16 households in north-east England, Gregson $(2007,24)$ argues that 'getting rid of things, along with sorting, holding and keeping them, and not just acquisition is fundamental' to the way in which humans make a homespace. As Dean's sense of completeness with respect to making a home suggests, for some older people who have had a lifetime of perfecting the act of appropriation and divestment, objects in the home are the result of an increased consciousness of identity subjectivity (Sherman and Dacher 2005). But of course appropriation and divestment of material items, which indeed are decisions based on class and wealth, among others, can be much more complex than this specific example would suggest.

As shown, interviewees Gerard and Dean share an approach which sees a gay trope linked to their experiences of material homemaking; similarly one additional participant draws on another stereotypical identity characteristic in his explanation of a domestic material object that relates to his sexuality. Adam noted the Royal Standard of Scotland conflates two aspects of his identity: his Scottish upbringing and his gay identity. Adam explained that the flag is flown at Edinburgh's Palace of Holyroodhouse year round, unless the Queen is in residence, and in light of the parlance which sees a gay man as 'queen', he feels that displaying it over his bed has a humorous double meaning. Adam's narrative showcases how a national flag can work in surprising ways to queer what many might assume is a typical domestic setting.

Adam also offers another example of an object in the home relating to his gay identity, and he also felt it does not outwardly reflect this aspect of his subjectivity in obvious ways. He comments: 'I have a rainbow thing, one of those things that hang down from the ceiling [that] twirls around ... I have one of those in my bathroom'. Although Adam suggests it is 'my [only] token demonstration of my sexuality' he felt that its significance is lost on some visitors. On the one hand a rainbow is quite recognisably related to gay identity and pride, and this object allows him to have something in his home that links him to the gay community, but on the other it does not declare his sexuality in obvious ways to his family, who sometimes visit and do not know he is gay. Both of these examples highlight the highly coded status of some domestic objects, where double meanings abound. One must be an insider, or in the know, to get the joke or understand the underlying signification: privacy is a layered thing. Thus, Adam feels unless one is privy to the history of the pride flag or to the double meaning of 'queen' then the significance remains private and personal. These layered objects queer heteronormativity in subjective and subtle ways. 
Photographs of same-sex partners were another common object that was displayed in the front rooms of some of the homes I visited. Rose (2003) has looked to the ways in which family photographs are arranged, displayed and viewed in the production of homespace (see also Tolia-Kelly 2004b). Displays of domestic family photographs are, Rose argues, mediated moments that show families at leisure, and at the same time erase 'family tension or conflict' (Rose 2003, 6, 2004, 550). Morrison extends this in her study of material constructions of heterosexuality at home by arguing that photographs of couples 'usually signify an important heterosexual event, such as engagement parties and weddings' $(2013,417)$. Morrison suggests the wedding photographs in particular are 'instrumental in performing heterosexuality in and through domestic space' (420). In light of this, I would argue that the material engagement and domestic display of same-sex family portraits, in particular those from civil partnership ceremonies, offer a queering of the most sanctioned heteronormative tradition of all: the normative marriage. ${ }^{2}$ Although same-sex couple portraits are not explicit, such as homoerotic artwork, they queer heteronormativity at home in different yet equally powerful ways - paralleling through interior design, the coded norms of homemaking.

One final theme was raised in a handful of interview transcripts with older participants that highlight the importance of material objects in the construction of identity: the display of mementos in the home. Objects in the home were discussed by interviewees because of their ability to act as a mnemonic anchor for past events (Chaudhury and Rowles 2005; Tolia-Kelly 2004a, 2004b). Dean, for instance, noted that a refrigerator door can be the perfect location to store the material objects that capture memories over the lifecourse. Looking at his refrigerator door one can see the conflation of his gay identity with other facets of self, including his love of animals and travelling. And Eric highlighted the importance of objects for their keepsake status from holidays abroad with his partner. He notes:

I treasure most the paintings [my partner] and I have acquired over many years. Each painting means something to us, or reminds us of an event or trip, and their purchases have always been

joint decisions (participant writing diary).

Eric makes clear that materiality is an important process through which 'meaningful domestic objects make the self present to self' (Gorman-Murray 2013, 110). Some older people have had a greater opportunity to collect memories and fill a home with objects from significant moments. Eric is one of them: 'At our stage of life ... you sort of accumulate things; this is your luggage ... This comes from China: it all has meaning.'

So far this article has explored the ways in which material objects in the homes of older gay Londoners works to queer heteronormativity in explicit, subtle and even hidden ways. Through arguing that materiality is an important lens to understand older gay Londoners' homes I suggest looking beyond possessions is an equally valuable method. Simply put, the avoidance of materiality connected to sexuality is a powerful act in and of itself and this is the theme that the remainder of this article focuses on.

\section{Looking beyond sexuality in representations of materiality}

In her study looking at the relationship between materiality and heterosexuality, Morrison (2013) found that most of her interviewees were unable to comprehend how their sexual identity relates to objects at home. The difference in focus in Morrison's and my own studies - dominant versus marginalised sexuality - might explain why many of my own participants, as discussed in the previous section, did in fact connect their sexuality with domestic objects. But I want to complicate this notion. In this section, I highlight how 
some participants contrastingly felt that sexuality is not related to material objects. Importantly, I show how this act works to queer heteronormativity in powerful ways too. Simply put, these participants use the same approach and visible representations as the vast majority of heteronormative society, thereby not signifying themselves or their homes as extraordinary - which is, as a I go on to show, a political act in and of itself.

Finding out about the avoidance of sexuality-identifying materiality in the home, in many interviews, became evident by asking if one would display objects related to gay culture, e.g. the rainbow flag. Roger offers a particularly interesting response:

The gay orientation is just part of me; it's not what I'm all about. If there was a straight flag I wouldn't hang that out the window either. For me, heterosexuality is as normal to me as homosexuality is; purely because I am one [a gay man] but I was brought up in general society as a straight society so I identify with both.

Roger's quote is telling because not only is he incredibly comfortable in his gay identity, and therefore does not relate to sexuality-identifying objects at home, but his sexual minority subjectivity is as normal to him as 'normal heterosexuality' is to society generally. His opinion and approach subverts dominant ideologies, including those by some queer theorists, which suggest gay identity is radically different compared to heterosexuality. Following on from this he notes:

Yes I'm gay because I sleep with men, I don't sleep with women, but other than that I don't really classify myself as a gay person. I'm not heavily into fashion, shopping, and all the stereotypical things that gay men are supposed to do. I'd rather be knocking a wall down.

Despite stereotyping most gay men, this quote shows that he is proud of his sexuality while at the same time does not desire to bring it to the fore in the way that others do.

Similarly, Eric suggests that he and his partner are completely 'out' to friends and family and, in light of the increased equality that the gay community has achieved in the West (Weeks 2007, 2-3), he suggests that there is no longer a need to visibly display objects in his home:

No I wouldn't display [the flag]. We have passed that stage now. Fortunately we don't live in Uganda. We live in a society where it's acceptable to be gay. [My partner] and I have entered a civil partnership we are totally and utterly accepted by our friends and families and there is no need to have these outward signs of being gay because people know, the ones who need to know know.

Following on from Roger's point above, Eric felt that his sexuality is 'not that important' and it does not reflect outwardly in his homemaking:

No [my home does not reflect our sexuality]. I don't see how it could! ... none of us have this desire or need to surround ourselves with things that remind us of our sexuality because it's not that important. There are other matters that are perhaps more important ... the moment everything becomes sexualised you don't see people for what they are.

Rather than foreground sexuality in his identity construction and material possessions, other facets of self are more important to Eric's homemaking. Dale similarly suggests that there is no need to foreground his sexual identity in the homemaking process. Apart from framed photographs from his civil union there are no obvious signs of his sexuality. He asserts: 'It's not some sort of seventies gay bar; it's just a house ... I don't see any signifiers'.

Peter also felt that in no way does the home he shares with his partner reflect their sexuality. Furthermore, the comfort they have in their sexual orientations and that their relationship is widely known on the street means that they have no need to relate this fact of their identities to material possessions. In response to the enquiry if he would display a rainbow flag, Peter remarks: 'No. I don't think my sexuality is any particular big deal ... 
The very last thing I would do is put up a rainbow flag, to be honest'. Although the rainbow flag can be a contentious issue, given its embodiment in sexual politics generally, which relates to a narrow understanding of gayness coming out of gay liberation politics, its visibility and ubiquity provide for rich responses like Peter's. His comfort in his sexuality was made particularly clear towards the end of our interview when we were talking about websites that he might use. His concise conclusive response is even more telling: "[We use] very little actually: we're not really that gay'. The view that sees one as 'not really that gay' carries certain judgements against those who are, on the contrary, 'particularly gay' - presumably those who fit into stereotypical notions of gay subjectivity. Basil and Barclay also align with the ongoing discussion. In our interview Basil noted, 'Bear in mind that we're not particularly gay orientated', and on another occasion he suggested, 'in most senses, we're not actively gay people'.

Many of the interviews in this section share a common identity intersection: comfort in one's sexual minority subjectivity. I suggest that for the majority of the older interviewees in this research the fact of living for several generations means there has been more time to come to terms with this aspect of subjectivity. It is important to foreground the specificity of the data, though. Recalling the methodological discussion above, many of the interviewees were of a similar class and socio-economic ability and furthermore were able bodied. Thus, many other people may not be able to relate to their sexuality in similar ways. Nevertheless, for some people there seems to be an implicit link between comfort in minority subjectivity and the desire to avoid identifying with one's sexuality through domestic materiality. The rejection of stereotypical notions of gay identity, for participants in this section, go hand in hand not only with the avoidance of sexuality-related materiality but also with the 'normalisation' of sexuality at home wherein other facets of self are more important; implicit to this is a desire to create a domestic space that shares homemaking features with the heteronormative home.

Darrell offers one example of an interviewee who aims to 'normalise' his minority identity by suggesting it is 'no big deal'. Gerard and Ritchie also touched on this topic. Gerard notes the degree to which gay sexuality is naturalised into everyday interactions: '... Do [my neighbours] know? Do they care? They probably have their suspicions ... I suspect they would probably be surprised that you're asking the question'. Ritchie offered a likewise opinion by stating, 'I think people are less curious than we think'. While these responses make gay sexuality seem ordinary and widely accepted - and indeed it may be in the lives of some Londoners - it is worth noting the geographical specificity of these comments. It is entirely feasible (and probable) that living in a large Western metropolis like London allows this sort of comfort with minority sexuality, but of course gay people living in other spaces would certainly illicit different responses.

By drawing attention to these quotes that show how these older gay participants do not raise their sexual minority identity to anything out of the ordinary, and as a result mention that other intersections of identity are more important generally and in the relationship to material objects specifically, I touch on a theme that Pugh discusses in one of his literature reviews: 'the message is quite clear, that happiness or satisfaction in later life is dependent on other factors rather than on sexual orientation per se' $(2002,170)$. Levels of comfort in one's sexuality result in interviewees being able to reject public material culture; that is, levels of comfort in society, beyond the home, reflect back to what these people do and do not do in their homes. Interestingly, comfort in society affects one's relationship to the domestic: it allows for one's home to be distinctly different to other gay homes and similar to the majority of heteronormative domestic spaces. ${ }^{3}$ Again, I acknowledge the specificity of the research. All interviewees noted that they are comfortable in their minority 
subjectivity and are, for the most part, out to family and friends. This will have certainly affected the findings; in other words, it takes a certain amount of self-acceptance to even respond to my call for participants. Not all older gay men are 'out' and other people may therefore rely on visibly identifiable objects as a connection to the community they belong to. However, through the avoidance of sexuality-based materiality and the 'normalisation' of their sexual subjectivity, these interviewees use a similar homemaking approach as the majority of heteronormative society, but that is not to suggest that these respondents' homemaking is not political.

Thinking about living arrangements, I asked every interviewee if they agree with the idea that 'home' consists of, for the majority of society, a nuclear family with a father, mother and a couple of children. Peter disagreed and suggested that his along with most contemporary living arrangements challenges this dated ideal. Devin, who lives alone, felt his living situation 'fit[s] into an increasing picture of UK domesticity'. In other words, 'there is a move away from the traditional 2.2 with the dog and the cat'. Gerard offers a similar opinion:

There are very few people that live like that. I know what you mean but I think if you start digging around it's a very different from the kind of experience that I would have or the people I know.

Some other interviewees complicate the notion that living situations queer traditional heteronormative domesticity by aligning with larger representations of home. Dale, for instance, agrees with the prevailing view that ideology is changing - 'it was probably the case when my parents were young' - however, he suggests that his homemaking process on the other hand in many ways aligns with it. He explains: 'It probably does [support that ideology]! [We do not have] kids, but we live in what could be termed the suburbs, we garden, cook, and are quite domestic'.

These few older gay interviewees who feel their ideal of domesticity has nothing to do with their sexual minority identity, whether through their relationship to domestic objects or the home more generally, deepen the argument that older gay men are queering heteronormativity at home. Although there is the possibility that these participants may be aligning with middle-class respectability and conservative homemaking, I suggest that there is more to it that support queer politics. I contend that many of the ways in which older gay men relate to the domestic sphere are political acts that work to queer heteronormativity; from the more obvious to the subdued - through identifying with sexuality in domestic objects, to lifestyle choices like living with a same-sex partner or inviting friends into one's home, and finally to removing the exceptionality of gay identity. Simply put, to show that older gay male occupied homes might look not dissimilar to a straight home challenges presumptions on a number of levels, including stereotypes of the way gay people live, and it urges a more detailed investigation of the way multiple subject positions work to create space. The fact that these participants can now reject sexuality altogether in the homemaking process is a political statement to how far queer politics has come. Because not everyone has the aspiration or luxury of rejecting aspects of their sexuality at home, celebrating the political agency of homemaking that challenges the all-encompassing nature of heteronormativity is important: even though some interviewees are not explicitly engaging in politics does not mean the need for politics disappears.

\section{Conclusion}

This article has drawn from interview data with older gay men living in London to understand relationships to materiality at home and how this negotiation supports a queer 
theorised agenda of queering heteronormativity. Along with foregrounding the subversiveness of homemaking, drawing from mature-age narratives of home has attempted to add to the small but growing body of literature situated at the intersection of gerontology, masculinity and materiality. In the preceding pages I have acknowledged the specificity of the findings: class, access to capital, comfort in one's sexual identity and a desire to make home are all factors that have shaped the research. The paper highlights the diversity within this small cohort. All participants were able to accumulate identity at home over the lifecourse, but yet read together one can see the fluidity of sexuality and materiality in the domestic sphere. Celebrating the multiple ways materiality plays out in these spaces, I have argued that this age cohort simultaneously challenges and even appear to support through homemaking practices (at least on the surface until one looks deeper) heteronormative ideals. Importantly, I have attempted to avoid presenting a basic binaristic view in which sexuality is either foregrounded through material objects or it is not. Such an approach, I argue, would reproduce simplistic polarised thinking which queer theory has sought to disrupt for nearly two decades.

As suggested, the narratives of older gay Londoners begin to show the ways in which materiality at home can work to subvert - in not always easy-to-recognise ways - larger discourses of oppression. Importantly, queering within the internal and private space of home does not mean that the power to destabilise larger discourses remains indoors and muted. One simply needs to recall Hanisch's (1969) maxim, 'the personal is political', to understand the power of homespace. Hooks has also influentially argued that home is a powerful space of agency: '... homeplace was the one site where one could freely confront the issue of humanization, where one could resist' (1990, 42). Thus, I would optimistically argue, if public discourse can have an outside-in effect and shape normative concepts of home, then equally studies focusing on queering home might work to reform normative ideals from inside-out: the British home is not as stable as it once was.

\section{Acknowledgements}

I thank the three anonymous reviewers, Dr Barbara Penner for encouraging me to publish this paper in Gender Place \& Culture, Dr Andrew Gorman-Murray for commenting on earlier versions and finally the interviewees who opened up their homes to me.

\section{Notes}

1. To protect anonymity pseudonyms are used throughout.

2. Read together, Smith (2010) and Rolfe and Peel (2011) offer more on this and position advanced arguments on how same-sex marriage and civil unions both challenge and support normative institutions.

3. See Ahmed $(2006,154)$ where she argues that queer and (dis)comfort go hand in hand; that there is a political agency in this ontology.

\section{Notes on contributor}

Brent Pilkey, a teaching fellow at the Bartlett School of Architecture, University College London, has recently completed his doctorate which utilised a queer theorised approach to architectural history. Previously he has completed an Honours Bachelor of Arts in architectural design and art history as well as a Master of Arts in art history at the University of Toronto, Canada. He has published in Geographical Research, Gender, Place and Culture, the gay press and is currently working on special issues for Local Environment and Home Cultures. 


\section{References}

Ahmed, Sara. 2006. Queer Phenomenology: Orientations, Objects, Others. Durham, NC: Duke University Press.

Andrews, Gavin, Malcolm Cutchin, Kevin McCracken, David Phillips, and Janine Wiles. 2007. "Geographical Gerontology: The Constitution of a Discipline." Social Science and Medicine 65 (1): $151-168$.

Baydar, Gülsüm. 2012. "Sexualised Productions of Space." Gender, Place and Culture: A Journal of Feminist Geography 19 (6): 699-706.

Brett, Philip, and Elizabeth Wood. 2006. "Lesbian and Gay Music." In Queering the Pitch: The New Gay and Lesbian Musicology, 2nd edition, edited by Philip Brett, Elizabeth Wood and Gary C. Thomas, 351-378. London: Routledge.

Brown, Gavin. 2009. "Thinking Beyond Homonormativity: Performative Explorations of Diverse Gay Economies." Environment and Planning A 41: 1496-1510.

Buchli, Victor. 2004. "Material Culture: Current Problems.” In A Companion to Social Archaeology, edited by Lynn Meskell, and Robert W. Preucel, 179-194. Oxford: Blackwell.

Chaudhury, Habib, and Graham D. Rowles. 2005. "Between the Shores of Recollection and Imagination: Self, Ageing, and Home." In Home and Identity in Late Life: International Perspectives, edited by Graham D. Rowles, and Habib Chaudhury, 3-18. New York: Springer.

Coleman, Peter. 1993. "Adjustment in Later Life." In Ageing in Society: An Introduction to Social Gerontology, edited by John Bond, Peter Coleman, and Sheila Peace. London: Sage.

Cook, Matt. Forthcoming. Queer Domesticities: Homosexuality and Home Life in Twentieth Century London. London: Palgrave.

Drummond, Murray. 2006. "Ageing Gay Men's Bodies." Gay and Lesbian Issues and Psychology Review 2 (2): 60-66.

England, Kim V. L. 1994. "Getting Personal: Reflexivity, Positionality, and Feminist Research." Professional Geographer 46: 80-89.

Gorman-Murray, Andrew. 2006. "Queering Home, Domesticating Deviance: Geographies of Sexuality and Home in Australia." PhD diss., Macquarie University.

Gorman-Murray, Andrew. 2008. "Reconciling Self: Gay Men and Lesbians Using Domestic Materiality for Identity Management." Social \& Cultural Geography 9 (3): 283-301.

Gorman-Murray, Andrew. 2013. "Liminal Subjects, Marginal Spaces and Material Legacies: Older Gay Men, Home and Belonging." In Queer Presences and Absences: Time, Future and History, edited by Yvette Taylor, and Michelle Addison, 93-117. London: Palgrave Macmillan.

Gregson, Nicky. 2007. Living With Things: Ridding, Accommodation, Dwelling. Wantage: Sean Kingston.

Hanisch, Carol. 1969. "The Personal is Political." Accessed 22 May 2012. http://www.carolhanisch. org/CHwritings/PIP.html

hooks, bell. 1990. "Homeplace: A Site of Resistance." In Yearning: Race, Gender, and Cultural Politics, edited by bell hooks, 41-50. Toronto: Between the Lines.

Hubbard Phil. 2008. "Here, There, Everywhere: The Ubiquitous Geographies of Heteronormativity." Geography Compass 2: 640-658.

Jones, Julie, and Stephen Pugh. 2005. "Ageing Gay Men: Lessons from the Sociology of Embodiment." Men and Masculinities 7: 248-260.

Kennedy, Elizabeth Lapovsky. 2006. "Telling Tales: Oral History and the Construction of PreStonewall Lesbian History." In The Oral History Reader, edited by Robert Perks, and Alistair Thomson, 271-281. London: Routledge.

Koestenbaum, Wayne. 1993. The Queen's Throat: Opera, Homosexuality and the Mystery of Desire. Cambridge, MA: Da Capo Press.

Macdona, V. King. 2009. "Older LGBTs: The Invisible Population.” Pink News, June 9. Accessed 28 January 2012. http://www.pinknews.co.uk/2009/06/09/older-lgbts-the-invisible-population/

McDowell, Linda. 1999. Gender, Identity and Place: Understanding Feminist Geographies. Oxford: Polity Press.

Miller, Daniel. 1987. Material Culture and Mass Consumption. Oxford: Blackwell.

Miller, Daniel. 2008. The Comfort of Things. Cambridge: Polity Press.

Milligan, Christine. 2009. There's No Place Like Home: Place and Care in an Ageing Society. Ashgate: Farnham. 
Morrison, Carey-Ann. 2013. "Homemaking in New Zealand: Thinking through the Mutually Constitutive Relationship between Domestic Material Objects, Heterosexuality and Home." Gender, Place and Culture 20 (4): 413-431.

Mowl, Graham, Rachel Pain, and Carol Talbot. 2000. "The Ageing Body and the Homespace." Area 32 (2): 189-197.

Noble, Greg. 2004. “Accumulating Being.” International Journal of Cultural Studies 7 (2): 233-256.

Pain, Rachel, Graham Mowl, and Carol Talbot. 2000. "Difference and the Negotiation of 'Old Age." Environment and Planning D: Society and Space 18: 377-393.

Percival, John. 2002. "Domestic Spaces: Uses and Meanings in the Daily Lives of Older People." Ageing and Society 22: 729-749.

Pilkey, Brent. 2012. "LGBT Homemaking in London, UK: The Embodiment of Mobile Homemaking Imaginaries." Geographical Research 51 (2): 159-165.

Pilkey, Brent. 2013. "Queering Heteronormativity at Home in London." PhD. diss., University College London.

Pugh, Stephen. 2002. "The Forgotten: A Community Without a Generation - Older Lesbians and Gay Men." In Handbook of Lesbian and Gay Studies, edited by Diane Richardson, and Stephen Seidman, 161-181. London: Sage.

Rolfe, Alison, and Elizabeth Peel. 2011. “'It's a Double-Edged Thing': The Paradox of Civil Partnership and Why Some Couples Are Choosing Not to Have One." Feminism \& Psychology 21 (3): 317-335.

Rose, Gillian. 2003. "Family photographs and domestic spacings: A case study." Transactions of the Institute of British Geographers 28 (1): 5-18.

Rose, Gillian. 2004. “'Everyone's Cuddled Up and It Just Looks Really Nice': An Emotional Geography of Some Mums and Their Family Photos." Social and Cultural Geography 5 (4): 549-564.

Sherman, Edmund, and Joan Dacher. 2005. "Cherished Objects and the Home: Their Meaning and Roles in Late Life." In Home and Identity in Late Life: International Perspectives, edited by GrahamD. Rowles, and Habib Chaudhury, 63-79. New York: Springer.

Slevin, Kathleen F., and Thomas J. Linneman. 2010. "Old Gay Men's Bodies and Masculinities." Men and Masculinities 12: 483-507.

Smith, Miriam. 2010. "Gender Politics and the Same-Sex Marriage Debate in the United States." Social Politics 17 (1): 1-28.

Tolia-Kelly, Divya P. 2004a. "Locating Processes of Identification: Studying the Precipitates of Re-memory through Artefacts in the British Asian Home." Transactions of the Institute of British Geographers 29 (3): 314-329.

Tolia-Kelly, Divya P. 2004b. "Materializing Post-Colonial Geographies: Examining the Textural Landscapes of Migration in the South Asian Home." Geoforum 35 (6): 675-688.

Varley, Ann, and Maribel Blasco. 2001. "Exiled to the Home: Masculinity and Ageing in Urban Mexico." European Journal of Development Studies 12 (2): 115-138.

Wahler, Jim, and Sarah G. Gabbay. 1997. "Gale Male Ageing: A Review of the Literature." Journal of Gay and Lesbian Social Services 6 (3): 1-20.

Waitt, Gordon, and Andrew Gorman-Murray. 2007. "Homemaking and Mature Age Gay Men 'Down-Under': Paradox, Intimacy, Subjectivities, Spatialities, and Scale." Gender, Place and Culture 14 (5): 569-584.

Weeks, Jeffrey. 2007. The World We Have Won. London: Routledge.

Young, Iris Marion. 2005a. "A Room of One's Own: Old Age, Extended Care and Privacy." In On Female Body Experience: 'Throwing Like a Girl' and Other Essays, edited by Iris Marion Young, 155-170. Oxford: Oxford University Press.

Young, Iris Marion. 2005b. "House and Home: Feminist Variations on a Theme." In On Female Body Experience: 'Throwing Like a Girl' and Other Essays, edited by Iris Marion Young, 123-154. Oxford: Oxford University Press.

\section{ABSTRACT TRANSLATIONS}

\section{La deconstrucción queer de la heteronormatividad en el hogar: londinenses gay mayores y la negociación de la materialidad doméstica}

Este artículo observa las experiencias de hombres mayores gays de involucramiento con los objetos materiales al realizar las tareas del hogar. Utilizando Londres como estudio de 
caso, se basa en once entrevistas en profundidad semiestructuradas. Utilizo estas narrativas para argumentar que las prácticas de las tareas hogareñas de los hombres mayores gays pueden avanzar una meta teorizada queer de una deconstrucción queer de la heteronormatividad. A través del artículo, la materialidad doméstica y la relación de los participantes a su identidad sexual minoritaria conforman el centro de atención; el análisis empírico remarca las formas obvias, sutiles e incluso ocultas en que los entrevistados subvierten la heteronormatividad a través de su relación con las posesiones en el hogar. Además, también utilizo extractos de transcripciones para mostrar que algunos entrevistados evitan conscientemente describir su sexualidad en el proceso de involucramiento con objetos materiales en el hogar; esto también, se argumenta, puede ser entendido como un acto político que desafía las ideas normativas del hogar. El artículo apunta a complementar un pequeño pero creciente cuerpo de literatura en la intersección del trabajo feminista sobre materialidad doméstica, geografías de la gerontología, la masculinidad en el en el envejecimiento y la teoría queer.

Palabras claves: materialidad doméstica; deconstrucción queer de la heteronormatividad; tareas del hogar; hombres gay mayores; Londres, Reino Unido

\section{在家酷儿化异性恋常规：伦敦老年同志与家庭物质性的协商}

本文检视老年男同志从事与家庭物品相关的家户打造经验。本研究以伦敦做为案 例研究, 取自十一个深度半结构访谈。我运用这些叙事, 主张老年男同志的家户打 造实践, 可以推进酷儿化异性恋常规的酷儿理论化目标。全篇文章中, 家户物质性 以及参与者与其少数性认同的关係, 构成了核心关照; 经验分析凸显了受访者透过 与家中所有物的连结, 以显着、隐晦、甚至是隐藏的方法颠覆异性恋常规的方式。 除此之外, 我亦将检视逐字稿的摘录, 展现部分的受访者有意识地避免将其性向连 结至从事家中物品安排的过程中; 而本文主张, 此举亦可被理解为挑战家的常规理 解的政治行动。本文旨在补充一个座落于女性主义家户物质性研究、老年地理 学、老龄化男性气概与酷儿理论交汇处的小众却逐渐成长中的文献。

关键词：家庭物质性; 酷儿化异性恋常规; 家户打造; 老年男同志; 伦敦; 英国 